\title{
Space use patterns of the endangered North Pacific right whale Eubalaena japonica in the Bering Sea
}

\author{
Alexandre N. Zerbini ${ }^{1,2, *}$, Mark F. Baumgartner ${ }^{3}$, Amy S. Kennedy ${ }^{1}$, \\ Brenda K. Rone ${ }^{1}$, Paul R. Wade ${ }^{1}$, Phillip J. Clapham ${ }^{1}$ \\ ${ }^{1}$ National Marine Mammal Laboratory, Alaska Fisheries Science Center, NOAA Fisheries, 7600 Sand Point Way NE, Seattle, \\ WA 98115-6349, USA \\ ${ }^{2}$ Cascadia Research Collective, 2181/2 $4^{\text {th }}$ Ave W, Olympia, WA 98501, USA \\ ${ }^{3}$ Biology Department, Woods Hole Oceanographic Institution, 266 Woods Hole Road, MS\#33, Woods Hole, MA 02543, USA
}

\begin{abstract}
Understanding habitat use of critically endangered North Pacific right whales (NPRWs, Eubalaena japonica) is important to better evaluate the potential effects of anthropogenic activities and climate change on this species. Satellite transmitters were deployed on individual right whales in 2004, 2008 and 2009 to investigate whether their space-use patterns in the Southeastern Bering Sea (SEBS) were influenced by environmental conditions and to assess habitat use in areas of human interest. Whales were monitored for an average of $40 \mathrm{~d}$ (range 29-58 d) between July and October, a period in which they inhabited the SEBS shelf. Individuals tagged in 2008-2009 (cold years) remained in the middle shelf domain, travelled at a slower rate and showed a spatially more restricted habitat use than a whale tagged in 2004 (a warm year). Monte Carlo tests suggested that NPRWs associated with the cold pool (remnant winter water in the bottom layer of the middle shelf domain) during cold years, which is likely due to higher copepod abundance and reduced competition with other copepod predators within the cold pool. Telemetry data indicated that a Critical Habitat designated by the US National Marine Fisheries Service encompasses the main feeding range of NPRWs in the Bering Sea. Two whales briefly visited the North Aleutian Basin, an area previously considered for oil and gas development. Small sample sizes precluded conclusive comparisons of space-use patterns among years with significantly different temperature regimes, but we hypothesize that habitat use in the SEBS varies with these regimes because of concomitant changes in the abundance of the whales primary copepod prey. Long-term evaluation of space-use patterns of NPRWs is required to further understand their habits in the feeding grounds in light of global warming and the potential for increased anthropogenic activities.
\end{abstract}

KEY WORDS: Eubalaena japonica $\cdot$ North Pacific right whale $\cdot$ Satellite telemetry $\cdot$ Oceanography Bering Sea $\cdot$ Conservation

\section{INTRODUCTION}

The zooplanktivorous North Pacific right whale (NPRW) Eubalaena japonica was once abundant across the North Pacific Ocean and the Bering Sea (Brownell et al. 2001, Shelden et al. 2005). However, intensive whaling during the $18^{\text {th }}$ and $19^{\text {th }}$ centuries dramatically reduced their abundance (Scarff 2001, Clapham et al. 2004). There is evidence that the pop-

\footnotetext{
*Corresponding author: alex.zerbini@noaa.gov
}

ulation was increasing after international protection was afforded to them in 1949 (Brownell et al. 2001), but illegal catches by the Soviet Union in the early 1960s almost exterminated the remaining populations of these whales and drastically impacted their recovery (Doroshenko 2000, Clapham \& Ivashchenko 2009). Two NPRW stocks have been proposed (Clapham 2004): a western population found in the Okhotsk Sea and the northwestern North Pacific, and

() The authors 2015. Open Access under Creative Commons by Attribution Licence. Use, distribution and reproduction are unrestricted. Authors and original publication must be credited.

Publisher: Inter-Research · www.int-res.com 
an eastern population in the Bering Sea and the Gulf of Alaska. The eastern population is believed to be the most endangered stock of whales in the world, with an estimated population size of only ca. 30 individuals in the Bering Sea (Wade et al. 2011). Little is known about habitat use by this population, but the scant existing data suggest that it now occupies a greatly reduced range in the southeastern Bering Sea (SEBS) compared to historical times (Shelden et al. 2005, Shelden \& Clapham 2006, Josephson et al. 2008, Gregr 2011). Historical information suggested that the preferred prey of NPRWs in the Bering Sea were copepods and euphausids (Omura et al. 1969), but more contemporary data indicate that Calanoid copepods constitute the whales primary prey in the SEBS (Tynan et al. 2001, Baumgartner et al. 2013)

The SEBS is a highly productive marine ecosystem characterized by a physically dynamic environment with an extensive seasonal sea-ice advance and retreat (Niebauer et al. 1999, Wiese et al. 2012). It supports large biomasses of various commercially valuable species and provides approx. $40 \%$ of the US fisheries catch (Wiese et al. 2012). The eastern Bering shelf is divided into a coastal, middle, and outer hydrographic domain, each separated by oceanographic fronts or transition zones (Coachman 1986). The inner front (located approx. at the $50 \mathrm{~m}$ isobath) divides the coastal and middle domain, and the middle front (at the $100 \mathrm{~m}$ isobath) divides the middle and outer shelf domains. A salinity front at the shelf break (180 $\mathrm{m}$ isobath) divides the outer domain from the slope waters. Each domain has defining characteristics in terms of their summer structure and copepod composition (Cooney \& Coyle 1982, Smith \& Vidal 1986, Coyle et al. 1996, Hunt et al. 2002): (1) the coastal domain is well mixed with Oithona spp., Pseudocalanus spp., Acartia spp., and Calanus marshallae present, (2) the middle domain is stratified into a warm wind-mixed surface layer and a cooler tidally-mixed bottom layer with assemblages dominated by Pseudocalanus spp., Acartia spp., and $C$. marshallae, and (3) the outer domain is stratified into 3 layers (wind mixed surface layer, transition zone, and tidally-mixed bottom layer) where oceanic copepods such as Neocalanus spp., Eucalanus bungii, and Metridia pacifica are dominant.

The Bering Sea is predicted to be among those regions most severely affected by global warming as relatively small changes in the heat content of the water column can have a disproportionately large effect on the spatial distribution and dynamics of sea ice (Sarmiento et al. 2004, Meier et al. 2005, Overpeck et al. 2005). The oceanography of the SEBS shelf is largely governed by the presence of winter sea ice, which in turn is driven by variability in winter winds and air temperature (Stabeno et al. 2001). Oscillations between 2 states, referred to as 'cold' and 'warm', occur on annual or multi-year time scales, such as between the warm years of 2000-2005 and the cold years of 2007-2010 (Overland et al. 2012, Stabeno et al. 2012). During cold years, sea ice extends over the SEBS and the bottom layer of the middle shelf domain remains especially cold during summer. This water, called the cold pool, originates as melted sea ice that has been mixed throughout the water column during winter, and is then isolated from surface air-sea fluxes due to stratification during early summer (Stabeno et al. 2001). The cold pool is a prominent and ecologically important summertime feature of the SEBS and is characterized by bottom temperatures in the middle shelf domain of $>2{ }^{\circ} \mathrm{C}$ (Stabeno et al. 2001, 2012). In contrast, warm years show little or no spring sea-ice over the shelf and consequently a much reduced or absent cold pool (Stabeno et al. 2012). These different temperature regimes result in distinct patterns in the distribution, density and abundance of taxa at multiple trophic levels in the SEBS (Hunt et al. 2011, Stabeno et al. 2012), possibly including NPRWs.

Understanding how environmental factors influence NPRW distribution and habitat use is important to better evaluate the potential effects of anthropogenic activities and climate change to this endangered population. During the summers of 2004, 2008 and 2009, satellite transmitters were deployed on NPRWs in their feeding grounds in the Bering Sea to assess their movements relative to a region recently designated as a Critical Habitat $(\mathrm{CH})$ by the US National Marine Fisheries Service (NMFS 2006), and areas of interest for human development. Furthermore, we investigated whether space-use patterns were influenced by environmental conditions (e.g. cold vs. warm years, presence and spatial extent of the cold pool). This study was primarily motivated by the need to understand the population characteristics and habitat use of NPRWs due to the potential future development of oil activities in the North Aleutian Basin (NAB) lease sales area in the SEBS.

\section{MATERIALS AND METHODS}

\section{Locating right whales}

Vessel surveys were conducted in 2004 (Wade et al. 2006) and vessel and aerial surveys in 2008 and 2009 to locate right whales. Surveys focused on an 
area of the SEBS where the majority of the recent (post-1970) NPRW records were reported in the summer (July to September) (e.g. Shelden et al. 2005). Visual searches during vessel surveys were carried out by a team of 3-4 observers located in high points on the ship during daylight hours and appropriate sighting conditions (e.g. Beaufort sea state $\leq 5$ ), but visual watches were maintained in all but the most extreme weather conditions to maximize the chance of finding whales. Vessel observers searched for right whales with the naked eye or with the assistance of low $(7 x)$ or high power $(25 x$, 'big eye') binoculars. Aerial visual searching was conducted from an airplane by 3 observers (Rone et al. 2012).

Passive acoustic monitoring and visual survey methods were employed in combination. This multidisciplinary approach was a proven, and effective method for locating NPRWs in 2004 (McDonald \& Moore 2002, Wade et al. 2006) and was again utilized in 2008-2009 surveys. Expendable Directional Frequency Analysis and Recording (DiFAR) sonobuoys were deployed along the vessel trackline to provide bearings to whale vocalizations (upsweeps and gunshots; Rone et al. 2012) detected in the survey area. DiFAR sonobuoys were also deployed from the airplane using methods described in Rone et al. (2012). Once NPRW calls were detected, location and distance to calling whale(s) were calculated according to McDonald \& Moore (2002), and Rone et al. (2012). The ship or aircraft was then diverted toward the calls to conduct a fine-scale visual search to locate the whales.

\section{Satellite telemetry}

Once right whales were seen and weather conditions were appropriate, rigid-hulled inflatable boats were launched for tag deployment. Satellite transmitters were attached to the bodies of NPRWs using a tagging pole in 2004 and a pneumatic tag launcher (Air Rocket Transmitter System [ARTS]) (Heide-Jørgensen et al. 2001) in the 2008-2009 surveys. Tagging took place at distances of 5-10 m from individual whales. The implantable configuration (single AA cell, Mold 177) of the SPOT 4 and 5 transmitters (Wildlife Computers) containing an Argos satellite platform transmitter terminal (PTT) was used in this study. The tags comprise 2 components: a cylindrical transmitter housing $(115 \times 20 \mathrm{~mm})$, and an anchoring system $(170-200 \mathrm{~mm}$ long [diameter $=8 \mathrm{~mm}$ ] stainless steel rod of with $30-50 \mathrm{~mm}$ retention barbs at the proximal end). When deployed, approx. $40 \mathrm{~mm}$ of the tag remains external to the body of the whale, with a $145 \mathrm{~mm}$ antenna and the saltwater switch extending out of the distal end of the tag.

The duty-cycle (on/off period) of all transmitters was configured to optimize data collection in the feeding grounds (for habitat use studies) and for maximizing tag longevity. In 2004, tags were programmed to transmit every third day with a max. daily allowance of 300 transmissions per day restricted to the period between 06:00 and 18:00 h Alaska Standard Time (AST). In 2008 and 2009, the same daily allowance was used but tags were programmed to transmit during two $6 \mathrm{~h}$ periods (05:00 to 11:00 $\mathrm{h}$ and 17:00 to 23:00 $\mathrm{h}$ AST) every day in August and September, and every second day thereafter.

Six satellite tags were deployed in NPRWs in the SEBS (Table 1). All the tagged individuals were assumed to be adults given their relatively large size. Transmissions were not received from one tag; thus, data from 5 transmitters were considered in the analysis. Individual photo-identification data were collected from all tagged whales and biopsy samples for sex determination were available from 4 individuals (Table 1). Sex was determined using genetic methods developed by Fain \& LeMay (1995) as described in Wade et al. (2006).

\section{Argos location filtering}

Satellite tags were monitored by Argos Data Collection and Location Service receivers on NOAA TIROS-N weather satellites in sun-synchronous polar orbits (Argos 1990). Locations were calculated by Argos from Doppler-shift data when multiple messages were received during a satellite's passage overhead. Argos location quality (LQ) data are classed in order of increasing accuracy $(\mathrm{B}, 0, \mathrm{~A}, 1,2,3)$, where verified accuracies for $\mathrm{LQB}=17.4 \pm 26.2 \mathrm{~km}, \mathrm{LQ0}=$ $4.9 \pm 5.3 \mathrm{~km}, \mathrm{LQA}=2.9 \pm 5.2 \mathrm{~km}, \mathrm{LQ} 1=1.5 \pm 1.5 \mathrm{~km}$, $\mathrm{LQ} 2=0.7 \pm 0.6 \mathrm{~km}, \mathrm{LQ} 3=0.4 \pm 0.3 \mathrm{~km}$, (Fadely et al. 2005).

The Speed-Distance-Angle (SDA) Argos filter (Freitas et al. 2008) was applied to all location qualities in order to remove locations that implied unlikely deviations from the track as well as unrealistic travel rates. This filter requires 2 main parameters including turning angles and maximum speed of travel. The default value of turning angle (Freitas et al. 2008) was used and the maximum speed was assumed to be $15 \mathrm{~km} \mathrm{~h}^{-1}$ (Mate et al. 1997). Exploratory analysis showed that the use of different max- 
Table 1. Summary of satellite tags (platform transmitter terminal [PTT] ID, location and date of tagging, movement from tagging location) deployed on North Pacific right whales Eubalaena japonica ( $\mathrm{M}=$ male, $\mathrm{F}=$ female) in the Southeastern Bering Sea in 2004, 2008 and 2009 surveys. Catalog ID is the number assigned to each tagged individual in the National Marine Mammal Laboratory photo-identification catalog

\begin{tabular}{|c|c|c|c|c|c|c|c|c|c|}
\hline PTT ID & Sex & $\begin{array}{l}\text { Deployment } \\
\text { date }\end{array}$ & $\begin{array}{l}\text { Oceano- } \\
\text { graphic } \\
\text { regime }\end{array}$ & $\begin{array}{c}\text { Catalog ID } \\
\text { number }\end{array}$ & $\begin{array}{l}\text { Tagging } \\
\text { location }\end{array}$ & $\begin{array}{c}\text { Transmission } \\
\text { days }\end{array}$ & $\begin{array}{c}\text { No. } \\
\text { locations } \\
\text { per } \\
\text { whale }\end{array}$ & $\begin{array}{c}\text { Total } \\
\text { distance } \\
\text { traveled } \\
(\mathrm{km})\end{array}$ & $\begin{array}{c}\text { Average } \\
\text { travel } \\
\text { rate } \\
\left(\mathrm{km} \mathrm{h}^{-1}\right)\end{array}$ \\
\hline 22849-04 & M & 10 Aug 2004 & Warm & NMML-27 & $\begin{array}{l}57^{\circ} 44.4^{\prime} \mathrm{N} \\
164^{\circ} 57.2^{\prime} \mathrm{W}\end{array}$ & - & - & - & - \\
\hline $22850-04$ & - & 10 Aug 2004 & Warm & NMML-28 & $\begin{array}{l}57^{\circ} 43.4^{\prime} \mathrm{N} \\
165^{\circ} 05.8^{\prime} \mathrm{W}\end{array}$ & 41 & 33 & 908.5 & 0.93 \\
\hline 21803-08 & M & 21 Aug 2008 & Cold & NMML-75 & $\begin{array}{l}56^{\circ} 55.3^{\prime} \mathrm{N} \\
164^{\circ} 27.1^{\prime} \mathrm{W}\end{array}$ & 58 & 262 & 586.0 & 0.42 \\
\hline 87636-09 & F & 25 Jul 2009 & Cold & NMML-24 & $\begin{array}{l}57^{\circ} 12.9^{\prime} \mathrm{N} \\
163^{\circ} 00.7^{\prime} \mathrm{W}\end{array}$ & 29 & 176 & 367.9 & 0.53 \\
\hline 87637-09 & F & 14 Aug 2009 & Cold & NMML-87 & $\begin{array}{l}57^{\circ} 17.3^{\prime} \mathrm{N} \\
163^{\circ} 46.8^{\prime} \mathrm{W}\end{array}$ & 35 & 65 & 633.1 & 0.74 \\
\hline 87772-09 & - & 26 Jul 2009 & Cold & NMML-09 & $\begin{array}{c}57^{\circ} 07.6^{\prime} \mathrm{N} \\
162^{\circ} 55.5^{\prime} \mathrm{W}\end{array}$ & 36 & 7 & 157.2 & 0.20 \\
\hline
\end{tabular}

imum speed limits (12 and $18 \mathrm{~km} \mathrm{~h}^{-1}$ ) did not influence the results. Distances between filtered locations were calculated assuming a great circle route (Mate et al. 2011). In order to compare movement rates of whales tagged in different years, distances from tagging location and movement rates were computed. With consideration to the different duty cycle of tags deployed in 2004 and 2008-2009 surveys, filtered Argos locations from the latter years were restricted to 3-d intervals to match the transmission schedule of the 2004 tags. A Kolmogorov-Smirnov non-parametric test (K-S test) was used to evaluate whether the distribution of daily movement rates was consistent across all whales (Zar 1998).

\section{Background climatology}

To examine right whale movements with respect to the presence and extent of the cold pool, temperature and salinity profiles collected with conductivity-temperature-depth (CTD) instruments during 1 August to 31 October from 1973 to 2005 in the Bering Sea and the Gulf of Alaska were acquired from the World Ocean Database (Boyer et al. 2009). Bottom temperature and bottom salinity data were extracted from each CTD cast; in areas where the water depth exceeded $1000 \mathrm{~m}$, the temperature and salinity at $1000 \mathrm{~m}$ was used instead of bottom values. These data were converted to a climatology (a set of longterm averages) over a regular grid with $1.260^{\circ}$ and $0.675^{\circ}$ resolution in longitude and latitude (respec- tively) producing roughly $50 \times 50 \mathrm{~km}$ grid cells in the Bering Sea. To create the climatology, annual means were first produced for all casts that fell within the geographic limits of a single grid cell, and then the grand mean of these annual means was used as the climatological value for that respective grid cell. Separate climatologies were produced for bottom temperature and bottom salinity.

\section{BASIS data}

Temperature and salinity profiles were collected using CTD on the continental shelf of the Bering Sea during 14 August to 1 October 2004 (145 casts), 11 to 27 September 2008 (32 casts), and 30 August to 28 September 2009 (102 casts) during the U.S. BeringAleutian Salmon International Survey (BASIS) program (Danielson et al. 2011). Bottom temperature and bottom salinity data were extracted from each CTD cast. Since the BASIS surveys did not cover the entire region spanned by the simulated whale tracks, the background climatology was used to provide bottom temperature and salinity values outside of the aerial extent of the BASIS stations. Property values were interpolated over a regular $1 \times 1 \mathrm{~km}$ grid using kriging (Cressie 1993) with separate, fitted, spherical semi-variogram models for bottom temperature and salinity. Annual anomaly grids were also generated by subtracting annual means for the SEBS (the area covered by BASIS surveys during 2004, 2008, and 2009) from each of the BASIS grids. 

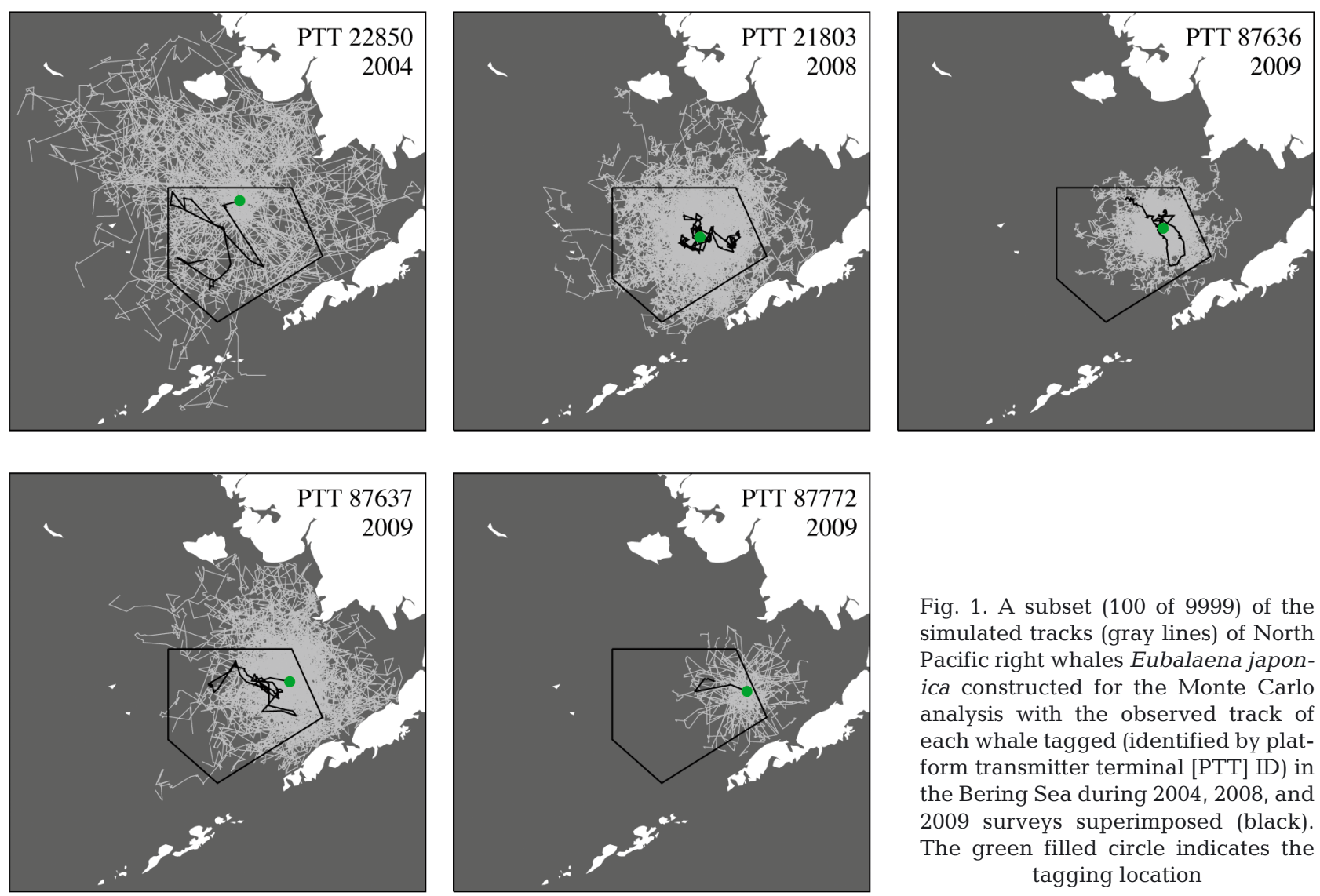

Fig. 1. A subset (100 of 9999) of the simulated tracks (gray lines) of North Pacific right whales Eubalaena japonica constructed for the Monte Carlo analysis with the observed track of each whale tagged (identified by platform transmitter terminal [PTT] ID) in the Bering Sea during 2004, 2008, and 2009 surveys superimposed (black). The green filled circle indicates the tagging location

\section{Monte Carlo tests}

Monte Carlo tests were used to test the hypothesis that the tagged right whales occurred within a single 'feature' (i.e. a discrete hydrographic regime or geographic area) more frequently than would be expected had they moved about the Bering Sea at random (after Baumgartner \& Mate 2005). To test this hypothesis, the distribution of 2 statistics of interest, (1) the number of Argos locations within a feature, and (2) the number of individual tagged whales within a feature, were developed using 9999 simulated tracks per tagged whale generated under the null model that the tagged whales moved at random (Fig. 1). A p-value was generated for each statistic by comparing the observed statistics to the distributions generated under the null model. One-way p-values are reported here, since we were primarily interested in areas preferred by right whales (i.e. with more locations or individuals than expected). Each of the whales 9999 simulated tracks started at the same location, comprised the same number of Argos locations, and covered the same total distance as the observed track; however, turning angles were drawn at random from a uniform distribution (Fig. 1). When a random turn angle resulted in a location on land or a track segment that crossed a substantial landmass (e.g. large islands), the turn angle was discarded and a new random turn angle was used. All environmental data (e.g. bottom temperature) from the BASIS grids were averaged within $7.5 \mathrm{~km}$ of all observed and random track locations. Details of the Monte Carlo test are provided in Baumgartner \& Mate (2005).

\section{RESULTS}

Transmitter average duration was $40 \mathrm{~d}$ (range $=$ 29-58 d, Table 1) and satellite tags provided information on the distribution and movements of NPRWs during July to October. A total of 552 locations were retained after filtering with the SDA filter, with 120 $(22 \%)$ of the locations being of high quality (Argos $\mathrm{LQ}=1-3$ ). In one case (PTT 87636-09), the satellite tag did not transmit for $9 \mathrm{~d}$ after tagging, but worked as programmed after this period. A second tag (PTT 87772-09) was deployed in a relatively low position 


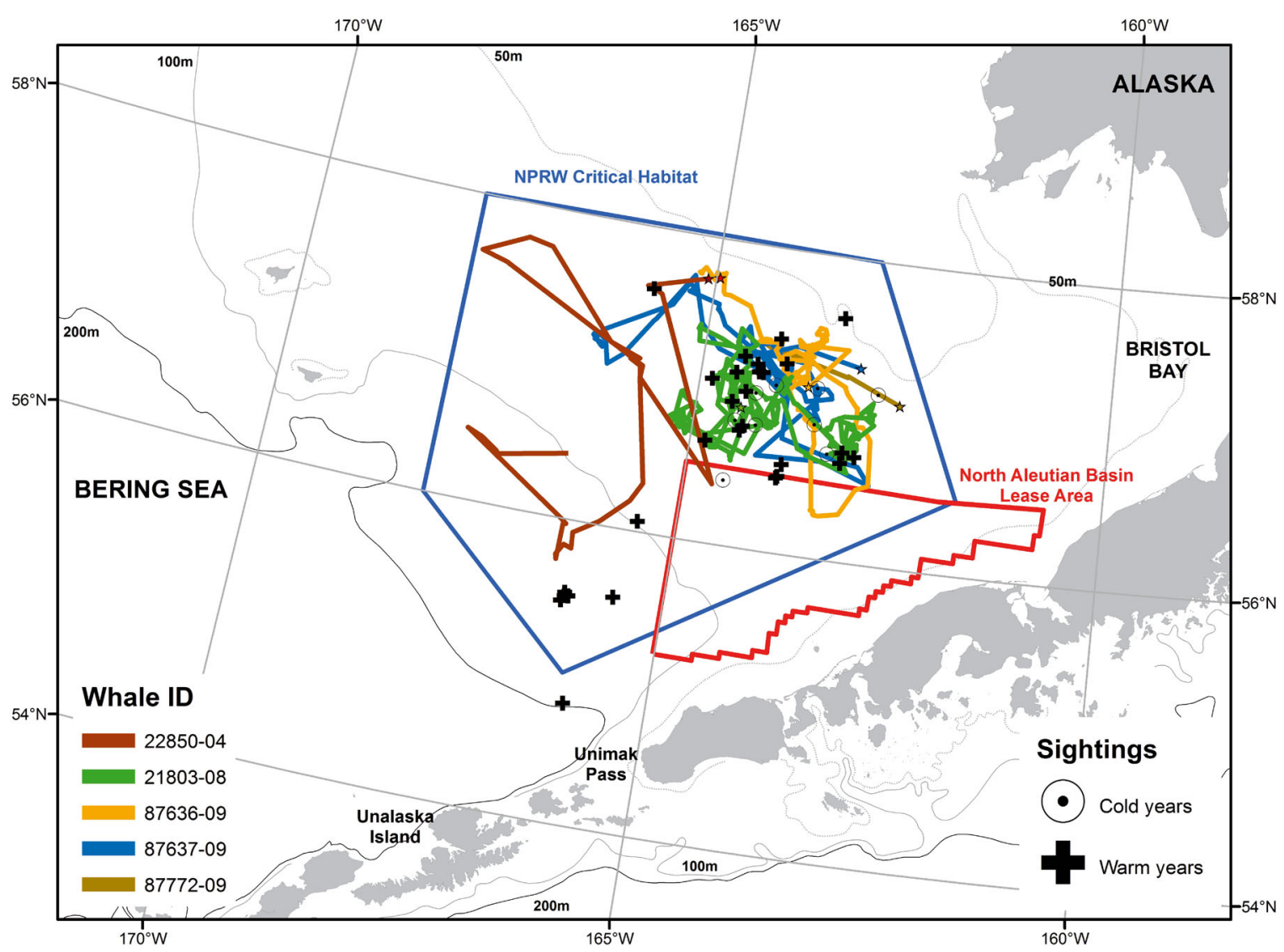

Fig. 2. Tracks of North Pacific right whales Eubalaena japonica tagged in the Southeastern Bering Sea in 2004, 2008, and 2009 and sighting data (1982-2006) in the inner (50 m isobath), middle $(100 \mathrm{~m})$ and outer $(200 \mathrm{~m})$ shelf domains in different temperature regimes (warm and cold years). Stars represent tagging locations (details given in Table 1), the blue polygon corresponds to the North Pacific right whale (NPRW) Critical Habitat in the Bering Sea and the red polygon to the North Aleutian Basin lease sales area

on the body and therefore provided only a few locations (Table 1).

NPRW movements in the SEBS were restricted to the middle and outer shelf west of Bristol Bay during the period the whales were tracked (Fig. 2). Differences in the movement patterns between the whale tagged in 2004 and those tagged in 2008-2009 were observed in terms of the areas used, travel rates and distances they moved from their tagging locations (Table 1, Figs. 2 \& 3). The individual tagged in 2004 (PTT 22850-04) typically moved at faster speeds (K-S test, $p=0.0430$ ) and remained further away from the location where it was tagged (Figs. 2 \& 3 ) than any of the whales tagged in 2008-2009. In addition, this was the only whale to explore more offshore habitats on the outer SEBS shelf, where it spent a minimum of $12 \mathrm{~d}$ (Fig. 2). In contrast, all whales tagged in 2008 and 2009 travelled at relatively slower rates (Table 1, Fig. 4), showed a more restricted habitat preference, and remained in the middle shelf (within the 50 and
$80 \mathrm{~m}$ isobaths) (Fig. 2) for the entire period they were tracked. None of the whales ventured into waters shallower than $50 \mathrm{~m}$ in any year (Fig. 2). There were significantly more Argos locations within the NMFS designated Critical Habitat $(\mathrm{CH})$ area than expected had the animals moved at random (Monte Carlo test, $p=0.0003)$, which suggests that the tagged right whales exhibited a preference for the area encompassed by the $\mathrm{CH}$ designation. Two individuals (PTT 22850-04 and PTT 87636-09) travelled into the NAB lease area, indicating that this region represents a portion of their habitat. However, these animals remained in the area for 2-3 $\mathrm{d}$, which correspond to only $5-7 \%$ of the time they were tracked.

The BASIS study plan included 29 stations in the SEBS that were sampled annually during 2004, 2008, and 2009. Average bottom temperature at these stations differed among years (1-way ANOVA; $F=$ 5.086, $\mathrm{p}=0.0082$ ) with significantly warmer temperatures in $2004\left(6.16 \pm 2.62^{\circ} \mathrm{C}\right.$, mean $\left.\pm \mathrm{SD}\right)$ than in 


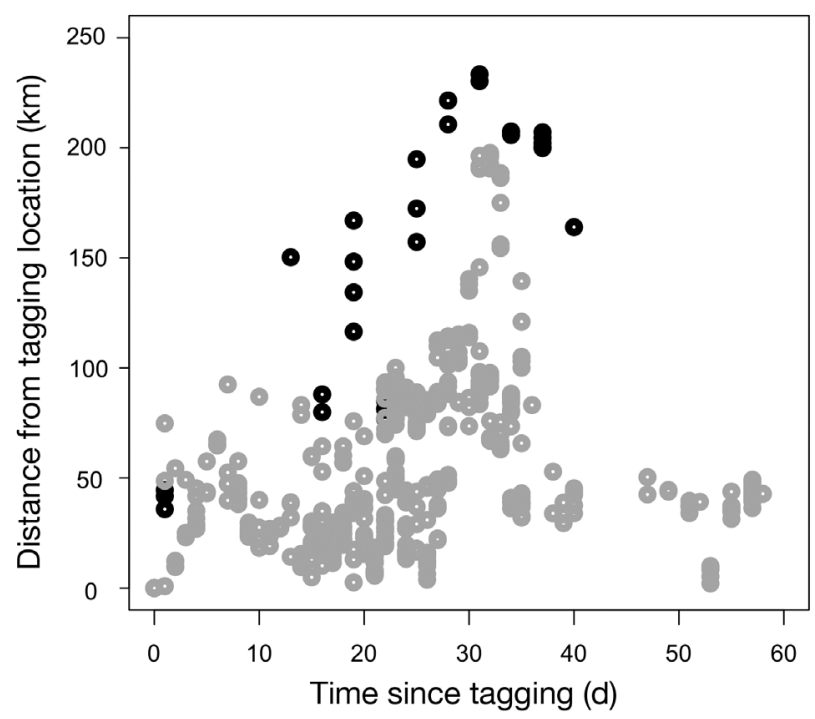

Fig. 3. Observed distances of tagged North Pacific right whales Eubalaena japonica from their initial tagging location. The whale tagged in the warm year of 2004 (๑) consistently remained further away from its tagging location than those tagged in the cold years of 2008-2009 (॰), indicating that it ranged over a greater spatial extent in the Southeastern Bering Sea

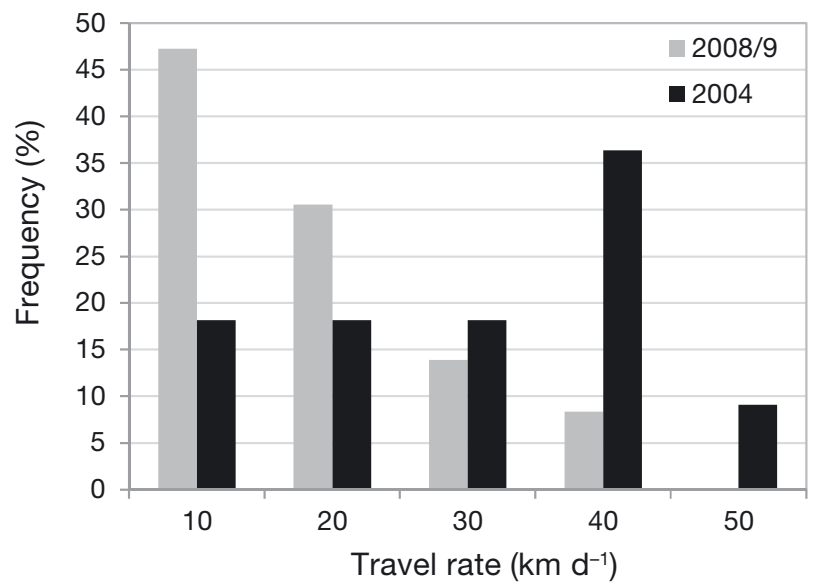

Fig. 4. Frequency distribution of travel rates of North Pacific right whales Eubalaena japonica tagged in the Southeastern Bering Sea. The individual tagged in 2004 moved at a faster rate than those tagged in 2008-2009

either $2008\left(4.06 \pm 2.64{ }^{\circ} \mathrm{C}\right)$ or $2009\left(4.29 \pm 2.97^{\circ} \mathrm{C}\right)$ (post-hoc Tukey HSD tests; $\mathrm{p}<0.05$ for both 20042008 and 2004-2009 comparisons). Average bottom salinity did not differ among years (1-way ANOVA; $F=1.006, \mathrm{p}=0.3700$ ). The cold pool (bottom temperatures $<2^{\circ} \mathrm{C}$ ) was present during the cold years of 2008 and 2009, but absent during the warm year of 2004 (Fig. 5).

The whales tagged during 2008 and 2009 were associated with the cold pool, whereas the individual tagged during 2004 explored a wider habitat (Fig. 5). Monte Carlo tests for the cold years (2008-2009) when the cold pool was present suggested that the tagged whales preferred the cold pool waters (Fig. 6a). Significantly more Argos locations $(n=104, p=0.0348)$ and tagged individuals $(\mathrm{n}=4, \mathrm{p}=0.0222)$ occurred in waters with bottom temperatures of $1-2^{\circ} \mathrm{C}$ and bottom salinities of 31.5-31.75. To account for interannual differences in oceanographic conditions, Monte Carlo tests were also conducted using annual anomalies of bottom temperature and salinity during 2008 and 2009 (Fig. 6b). These tests indicated that significantly more Argos locations $(\mathrm{p}<0.01)$ and tagged individuals $(\mathrm{p}<0.01)$ occurred in areas where bottom waters were $2-4^{\circ} \mathrm{C}$ colder than the annual mean temperature and within \pm 0.25 of the annual mean salinity in the SEBS (Fig. 6b).

\section{DISCUSSION}

\section{Habitat use in the Southeastern Bering Sea}

Historically, NPRWs were widely distributed in the Bering Sea and the Aleutian Islands during their feeding season (June to October). Whaling catches and sighting data from the early 1800 s to the 1960 s suggest that whales were regularly found in the middle and outer shelf domains, the slope and the Bering Sea basin as far north as the Bering Strait (Shelden et al. 2005, Josephson et al. 2008). Since the 1960s, when the majority of NPRWs in the eastern Bering Sea and Gulf of Alaska were illegally taken by the Soviet Union (Ivashchenko \& Clapham 2012), the range of these whales in their feeding grounds appears to have diminished (Shelden et al. 2005). Contemporary information (post-1980s) indicates that the middle shelf currently constitutes the primary habitat of NPRWs in the SEBS during the summer. Despite substantial survey effort throughout the Bering Sea shelf and the Aleutian Islands from various sources, e.g. aerial and vessel surveys (LeDuc et al. 2001, Tynan et al. 2001, Moore et al. 2002, Wade et al. 2006, Zerbini et al. 2006, Friday et al. 2012, 2013) and acoustic surveys (Munger et al. 2008, Stafford et al. 2010), recent data have shown that the only region in the Bering Sea where NPRWs have been consistently sighted is the middle shelf domain to the west of Bristol Bay (LeDuc et al. 2001, Shelden et al. 2005, Wade et al. 2006, 2011). This study provides further evidence that the NPRWs preferred habitat in the eastern Bering Sea corresponds to the southeast middle shelf domain. 

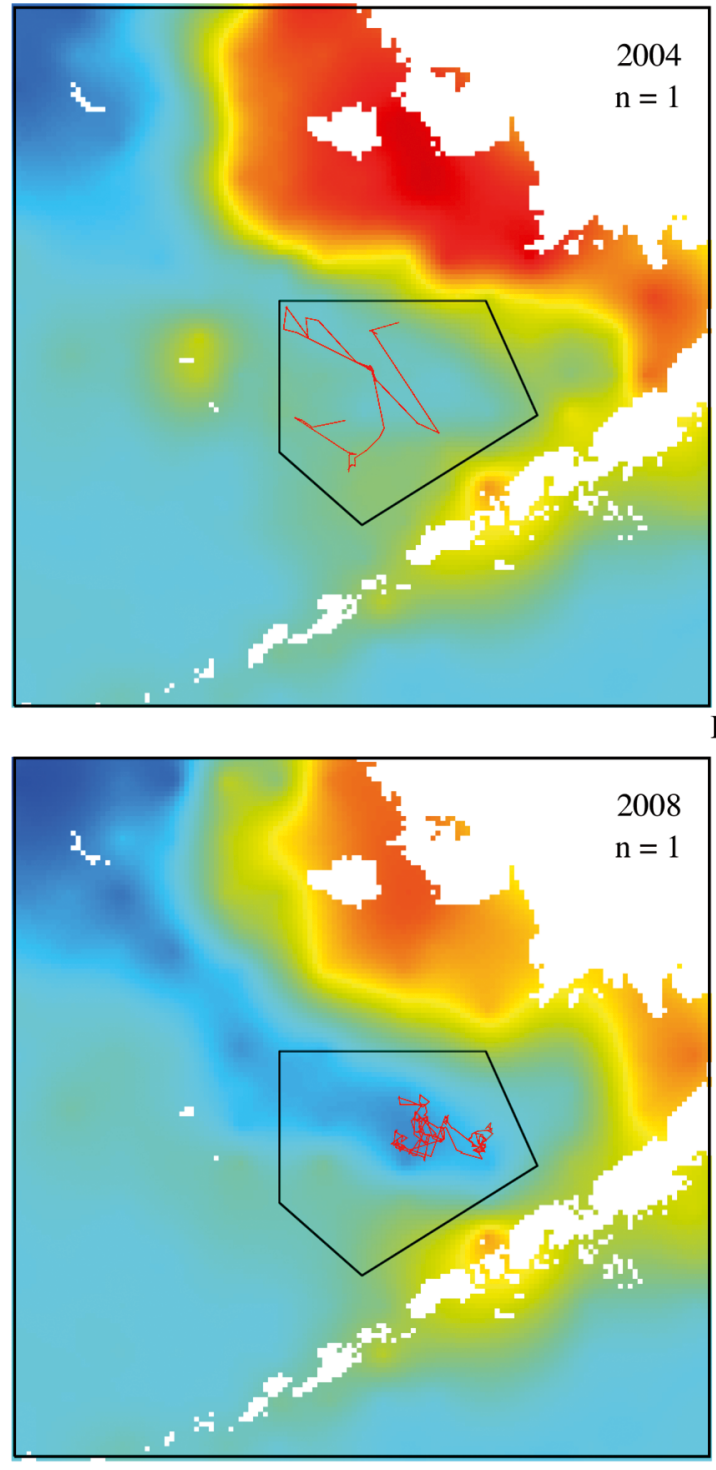

Bottom

temp.

$\left({ }^{\circ} \mathrm{C}\right)$

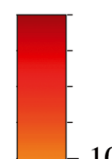

$-10$
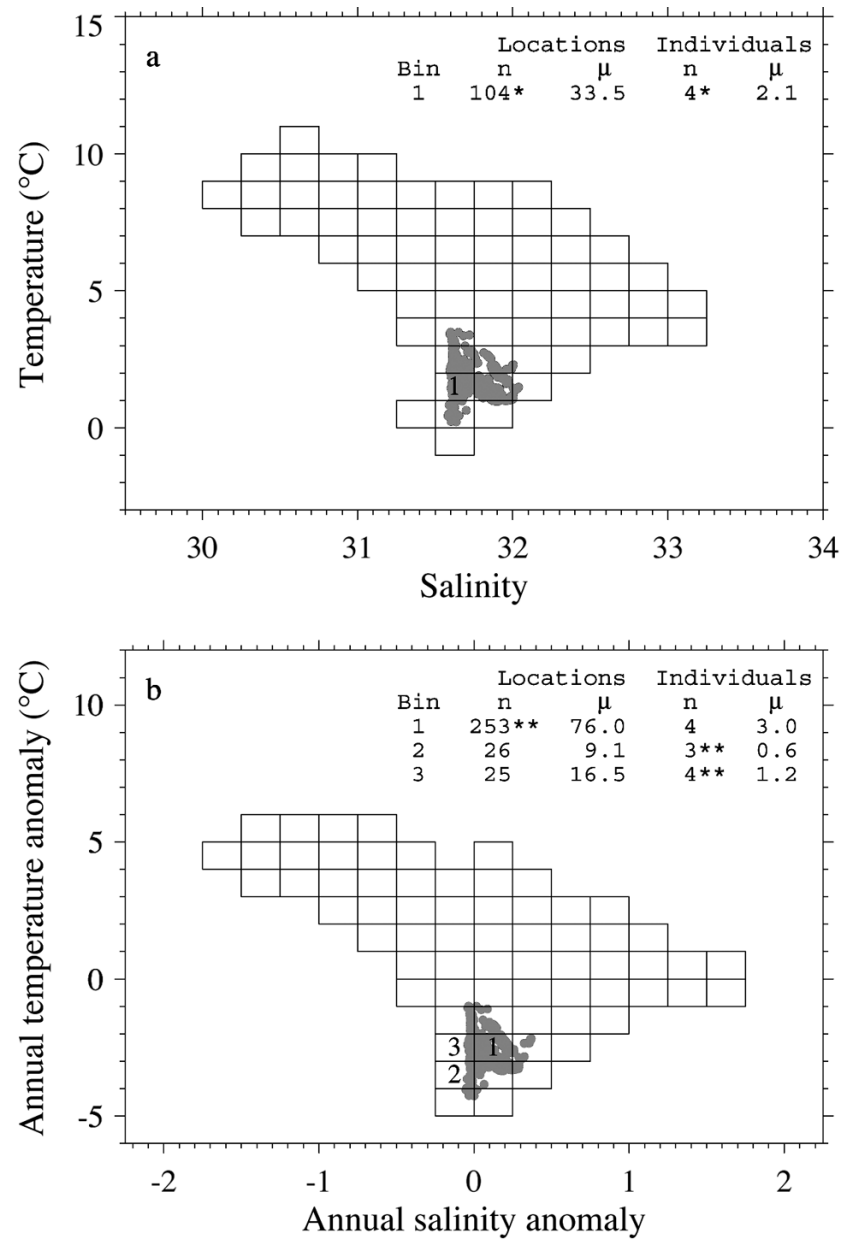

Fig. 6. (a) Distribution of bottom temperature and salinity at Argos-acquired locations for North Pacific right whales Eubalaena japonica tagged in 2008 and 2009 (gray circles) and the results of one-tailed Monte Carlo tests of habitat preference. (b) Distribution of bottom temperature and salinity anomalies (derived from annual mean temperature and salinity conditions in the Southeastern Bering Sea during 2008 and 2009), as well as the results of 1-tailed Monte Carlo tests of habitat preference. Boxes indicate 2-dimensional bins in which Monte Carlo tests were conducted. Numerals denote bins in which a significant number of locations and/or individuals occurred. For each labeled bin, the inset table shows the observed number (n) of locations or individuals and the mean number $(\mu)$ of locations or individuals in the sampling distribution of $\mathrm{n}$ under the null hypothesis of random movement. ${ }^{*} \mathrm{p}<0.05,{ }^{* *} \mathrm{p}<0.01$ 
This reduced contemporary summer distribution of right whales is likely a consequence of the small population ( 30 whales) inhabiting the SEBS (Wade et al. 2011).

This study also indicates that NPRW movement and occupancy patterns may differ depending on environmental conditions, possibly due to the influence of these conditions on the distribution and abundance of their zooplankton prey. Examination of stomach contents of NPRWs taken by whaling operations in the North Pacific and the Bering Sea during the 1950s and 1960s indicated that right whales feed on copepods (Calanus spp., Metridia spp., and Neocalanus spp.) and euphausids (Euphausia pacifica) (Omura 1958, Omura et al. 1969). C. marshallae was the dominant species in contemporary zooplankton sampling conducted near right whales in the SEBS middle shelf (Tynan et al. 2001, Baumgartner et al. 2013), suggesting that these copepods constitute the primary prey of NPRWs in the Bering Sea shelf. Note that we refer here to the copepod of the Calanidae family found in our study area as C. marshallae, but we recognize that there is some taxonomic confusion at present between this species and C. glacialis in the eastern Bering Sea (R. Campbell pers. comm.).

The primary productivity of the spring bloom in the Bering Sea is controlled mainly by oceanic conditions of temperature and sea ice extent, and variability in these oceanographic conditions is known to affect higher trophic levels (Stabeno et al. 2001, Hunt et al. 2002, 2008). For example, temperature regime has been shown to greatly influence the diversity and biomass of zooplankton in the SEBS shelf (Coyle et al. 2011, Stabeno et al. 2012, Eisner et al. 2014), including large copepods. The SEBS has exhibited extreme variability in sea ice extent, temperature and distribution and abundance of multiple trophic levels over the last 40 years (Overland et al. 2012, Stabeno et al. 2012). The high variability in sea-ice extent observed from the early 1970 s to 2000 was followed by a multi-year 'warm' period with consistently low sea ice (2000-2005). This period transitioned to a $4 \mathrm{yr}$ 'cold' regime of extensive sea ice (2007-2010). High and low periods of spring ice extent were associated with cold and warm water column temperatures in the following summer and spring, respectively (Stabeno et al. 2012).

This study suggests that NPRWs associate with the cold pool in the SEBS middle shelf domain during cold regime years (2008-2009) (Fig. 5). We hypothesize that habitat use patterns exhibited by right whales during this period were likely influenced by the distribution and increased abundance of their primary prey, C. marshallae (Baumgartner et al. 2013). Cold years are characterized by more extensive sea-ice in the SEBS shelf (Stabeno et al. 2012), which has been positively correlated with spring abundance of $C$. marshallae stages 1-5 copepodids (Baier \& Napp 2003). In addition, C. marshallae benefits from cold, icy winters in the SEBS because (1) ice algae or ice associated phytoplankton blooms provide an early spring food source, (2) colder winters with ice presence may reduce metabolism and lipid utilization, which may, in turn, increase winter survival (Coyle et al. 2011, Sigler et al. 2014), and (3) summertime C. marshallae mortality from walleye pollock and Pacific cod predation may be substantially reduced in cold years because the cold pool prevents access to the middle shelf domain for these fish (Swartzman et al. 1994, Ciannelli \& Bailey 2005, Kotwicki et al. 2005) (hypothesis posed by Stabeno et al. 2012). C. marshallae abundance in the SEBS was strongly related to the multi-year (2007-2010) cold period with significantly higher abundances and biomasses (particularly in 2008 and 2009) than previous warmer (2000-2005) or highly variable (pre-2000) years (Coyle et al. 2011, Stabeno et al. 2012, Eisner et al. 2014). Therefore, the relatively restricted movements exhibited by NPRWs during 2008 and 2009 may have been driven by large biomasses of $C$. marshallae and reduced competition for these copepods by walleye pollock and Pacific cod within the cold pool.

The movement patterns of the single whale tagged in 2004 differed from individuals monitored in subsequent years. This whale moved at relatively faster rates, used a wider range, and explored multiple habitats (e.g. middle and outer shelf domains). Given the small sample size, it is not possible to determine with certainty what led this individual to behave differently; possible reasons may include variation in sex, age, individual preference for certain habitats, or a combination of these factors. However, we hypothesize that this whale explored the outer Bering Sea shelf because foraging conditions on the middle shelf during 2004 (a warm year) were less profitable. The middle shelf summer abundance of $C$. marshallae in 2004 was 4 orders of magnitude lower than the abundance in 2008 (Coyle et al. 2011), perhaps indicating that there was insufficient biomass to maintain the energetic requirements of NPRWs. Low C. marshallae abundance may have motivated this individual to explore other habitats in search of prey. The outer shelf domain was possibly an attractive foraging habitat for NPRWs because of the unusually 
dense patches of C. marshallae and the relatively high abundances of another potential NPRW prey, Neocalanus spp., observed in the region during 2004 (Coyle et al. 2008, Hunt et al. 2008). In fact, multiple sightings and an aggregation of at least 17 NPRWs (Fig. 2), comprising more than half of the estimated population size, were observed over the outer shelf in 2004 (Wade et al. 2006). This relatively large number of records, in addition to the fact that half of the estimated NPRW population in the SEBS were seen in the outer shelf, provides further evidence that this region constituted a suitable habitat for the species in 2004.

None of the whales tagged in the SEBS visited the coastal domain (depth $<50 \mathrm{~m}$, as defined by Coachman 1986), an observation that is consistent with contemporary sighting data (Shelden et al. 2005). It is not yet clear why NPRWs show a preference for the middle shelf domain, despite the presence of their primary prey in the inner domain (Eisner et al. 2014). In the SEBS, the inner front near the $50 \mathrm{~m}$ isobath separates the well-mixed water of the inner shelf from the 2-layered, stratified water of the middle shelf domain (Coachman 1986, Kachel et al. 2002). The dynamics associated with this front are thought to influence the distribution of nutrients and phytoplankton and to attract upper trophic level species (Hunt et al. 1996, Kachel et al. 2002). Accordingly, Tynan et al. (2001) suggested that NPRWs predictably occurred near or south of the inner front because frontal features and stratification there played an important role in concentrating copepods, an important source of food for right whales. However, Baumgartner et al. (2013) conducted extensive oceanographic and zooplankton sampling near NPRWs in the middle shelf domain, and found no evidence that horizontal gradients in bathymetry, horizontal gradients in hydrographic properties (fronts), or stratification influenced the distribution or abundance of either $C$. marshallae or NPRWs. Based on their observations, Baumgartner et al. (2013) hypothesized that tidal resuspension of phytodetritus may attract and concentrate $C$. marshallae at depth in the middle shelf domain, a process that depends on the 2-layer stratification present at that depth to populate resuspended clouds of phytodetritus with $C$. marshallae (Baumgartner et al. 2013, their Fig. 8); however, this process could not occur in the well-mixed coastal domain. Further research is needed to better understand the physical and biological processes that aggregate copepods for the benefit of NPRWs, as we suspect these processes occur more frequently or exclusively over the middle shelf domain and may explain the right whales' apparent preference for this part of the Bering Sea.

A significant limitation of this study is its sample size. There were 2 individuals tagged in 2004 (but only one provided data), 1 in 2008 and 3 in 2009. The tracks of the satellite-monitored whales were consistent with contemporary (1982-2005) sighting data (Shelden et al. 2005, Wade et al. 2006, our Fig. 2) perhaps suggesting that habitat use displayed by the satellite monitored animals is representative of the NPRW population in the SEBS. However, this relatively small sample of tracked whales precluded a more comprehensive comparison between the movements of the whales tagged in warm (2004) and cold years (2008-2009). Differences in daily travel rates and extension of the habitat use during the season led us to hypothesize that the space-use-patterns of right whales during summer in the SEBS may vary in different temperature regimes, similar to what was observed for other large whales (Stabeno et al. 2012). In cold years, whales may associate with the cold pool of the middle shelf domain to take advantage of high biomasses of their primary prey and reduced competition from fish. In contrast, during warmer years, lower C. marshallae abundance may require whales to expand their foraging habitat, perhaps in an attempt to exploit more localized patches of this species or to look for other potential prey regularly found on the outer shelf, such as Neocalanus spp. (Coyle et al. 2008). In 2005, a warm year, the United States National Marine Mammal Laboratory (NMML) conducted a 2-wk acoustic and visual right whale survey primarily on the middle Bering Sea shelf (nearly identical to the 2004 survey) (Wade et al. 2006) and detected no right whales (P. R. Wade unpubl. data), suggesting that the whales were foraging in a different location. Further multi-disciplinary research is needed to evaluate the hypothesis that right whales change their space-use patterns in response to large-scale changes in oceanographic conditions. Such research would include additional short and long-term tracking, passive acoustic monitoring, and visual surveys. Testing this hypothesis is vital to understanding how NPRWs will respond to long-term changes in the environment. If climate change results in significant warming of the Bering Sea (IPCC 2007), the conditions observed during 2004 may predominate. Thus, it is possible that the environmental conditions required for high abundance of right whale prey in the SEBS will change substantially (Lee et al. 2013, Eisner et al. 2014), with potentially significant effects to the recovery of this critically endangered species. 


\section{Management implications}

The findings of this study have important implications for management. For example, the National Marine Fisheries Service (NMFS) designated areas within the Gulf of Alaska and Bering Sea as Critical Habitat $(\mathrm{CH})$ under the US Endangered Species Act (NMFS 2006). The proposed $\mathrm{CH}$ boundaries in the SEBS (Fig. 2) were developed based on modern (post-1980s) summer records and are believed to reasonably represent the area in which NPRW prey concentrations are most likely to occur. However, the designation was established based on sparse information collected during studies that were conducted from the late spring to early fall. NMFS (2006) noted that further review of $\mathrm{CH}$ should be conducted in the future, but this required additional data on distribution, habitat use, and movements. The results of this study show that whales monitored via satellite telemetry remained inside the NPRW $\mathrm{CH}$ in the Bering Sea over time scales of several weeks, and therefore provide further evidence that this region, as currently defined, encompasses an important habitat for this population in the summer.

Results presented here are also relevant to further decisions about future exploration of oil and gas in the SEBS. Indeed, our right whale satellite telemetry studies were primarily motivated by the potential for oil exploration and production activities in the NAB lease sales area, and while the NAB is no longer under consideration as a lease sale area, this could be reconsidered at any time in the future. The whales tracked during the present study largely remained to the north and outside of this area. Two individuals (PTT 22850-04 and PTT 87636-09) made incursions within the NAB for periods ranging from 2 to $3 \mathrm{~d}$ while they were monitored. Therefore, the movement patterns of these individuals indicate that the NAB area is at least occasionally used by right whales during their summer feeding season. Because the space-use behavior of right whales may be correlated with oceanographic variability, usage of this area could vary according to environmental conditions (e.g. in different temperature regimes) and requires long-term evaluation. In addition, the tagged whales remained in close proximity to the NAB lease area and therefore they may still be vulnerable to anthropogenic activities conducted in this region (e.g. acoustic disturbance by seismic exploration), even if they don't often physically occupy the habitat encompassed by that area.

Current threats to NPRWs in the SEBS are poorly known, but given its small population size ( 30 indi- viduals) (Wade et al. 2011), any human activity (e.g. shipping, fishing, oil and gas exploration and extraction) likely presents some risk to recovery. For example, it has been suspected that the behavior of right whales may make them more vulnerable to ship collisions than any other large whale species (IWC 2001). In fact, collision with vessels is the main source of mortality of North Atlantic right whales on the eastern coast of the US (IWC 2001). The results presented here indicate that the summer range of the species partially overlaps with shipping routes and some of the world's most intensive fishery areas (Nuka Research Planning Group 2005). Increasing human activities in the SEBS, including the potential for greatly increased trans-polar shipping traffic as a result of diminishing sea ice in the Arctic, will likely expose NPRWs to greater threats. Therefore further development of such activities (e.g. oil and gas exploration and shipping) needs to be carefully planned and managed, and to take into account long-term spatial and temporal patterns of NPRW distribution and habitat use in the Bering Sea.

Acknowledgements. Assistance with field work was provided by Billy Adams, Catherine Berchok, Cynthia Christman, Jessica Crance, John Durban, Carter Esch, Jeff Foster, Greg Fulling, Yulia Ivashchenko, Don Ljungblad, Nadine Lysiak, Tony Martinez, Laura Morris, Lisa Munger, Sarah Mussoline, Richard Pace, Robert Pitman, Desray Reeb, Allan Sauter, Franchesco Scattorin, and Suzanne Yin. Tag deployment in 2004 and 2008 were performed by Anders and Mikkel Jensen, respectively, and small boat driving during tagging operations was professionally carried out by B. Adams, T. Martinez, and S. Yin. Advice about the development of tagging technology was provided by Mads Peter Heide-Jørgensen, Mikkel Jensen, Ygor Geyer, Jim North and Robert Wagner. L. Eisner provided access to the BASIN data. J. Crance and K. Shelden provided reviews that improved early drafts of this manuscript. Assistance from the captain and crew of the ships used during the NMML 'PRIEST' cruises and 2004 right whale cruise in the Bering Sea as well as the tremendous effort of observers and acoustic teams in finding right whales is greatly appreciated. Tag deployment, photo-identification and biopsy sampling were performed according to regulations and restrictions specified in a permit issued by the National Marine Fisheries Service to the National Marine Mammal Laboratory (permit \#782-1719-03). Funding for this research was provided by the North Pacific Research Board (NPRB, Project \#720) and by the former Minerals Management Service (now Bureau of Ocean Energy Management, BOEM). This paper is contribution 558 from NPRB. Reference to trade names does not imply endorsement by the NOAA National Marine Fisheries Service. The findings and conclusions in this paper are those of the authors and do not necessarily represent the views of the NOAA National Marine Fisheries Service. This study is dedicated to the late Captain Atle Remme. Atle had a passion for whales and whale research. He was not only a great captain but, most importantly, a good friend. 


\section{LITERATURE CITED}

Argos (1990) User's manual. Service Argos, Landover, MD

- Baier CT, Napp JM (2003) Climate-induced variability in Calanus marshallae populations. J Plankton Res 25: 771-782

Baumgartner MF, Mate BR (2005) Summer and fall habitat of North Atlantic right whales (Eubalaena glacialis) inferred from satellite telemetry. Can J Fish Aquat Sci 62: 527-543

Baumgartner MF, Lysiak NSJ, Esch HC, Zerbini AN, Berchok CL, Clapham PJ (2013) Associations between North Pacific right whales and their zooplanktonic prey in the southeastern Bering Sea. Mar Ecol Prog Ser 490: 267-284

Boyer TP, Antonov JI, Baranov OK, Garcia HE and others (2009) World Ocean Database 2009. S Levitus S (Ed) NOAA Atlas NESDIS 66. Government Printing Office, Washington DC, p 216

Brownell RL, Jr., Clapham PJ, Miyashita T, Kasuya T (2001) Conservation status of North Pacific right whales. J Cetacean Res Manage (Special Issue 2):269-286

- Ciannelli L, Bailey KM (2005) Landscape dynamics and resulting species interactions: the cod-capelin system in the southeastern Bering Sea. Mar Ecol Prog Ser 291: 227-236

Clapham PJ, Ivashchenko Y (2009) A whale of a deception. Mar Fish Rev 71:44-52

Clapham PJ, Good C, Quinn SE, Reeves RR, Scarff JE, Brownell RL Jr (2004) Distribution of North Pacific right whales (Eubalaena japonica) as shown by 19th and 20th century whaling catch and sighting records. J Cetacean Res Manag 6:1-6

Coachman LK (1986) Circulation, water masses, and fluxes on the southeastern Bering Sea shelf. Cont Shelf Res 5: 23-108

Cooney RT, Coyle KO (1982) Trophic implications of crossshelf copepod distributions in the Southeastern Bering Sea. Mar Biol 70:187-196

Coyle KO, Chavfur VG, Pinchuk AI (1996) Zooplankton of the Bering Sea: a review of Russian-language literature. In: Mathisen OA, Coyle KO (eds) Ecology of the Bering Sea: a review of Russian-language literature. Alaska Sea Grant College Program, Fairbanks, AK

Coyle KO, Pinchuk AI, Eisner LB, Napp JM (2008) Zooplankton species composition, abundance and biomass on the eastern Bering Sea shelf during summer: The potential role of water-column stability and nutrients in structuring the zooplankton community. Deep-Sea Res II 55:1775-1791

> Coyle KO, Eisner LB, Mueter FJ, Pinchuk AI and others (2011) Climate change in the southeastern Bering Sea: impacts on pollock stocks and implications for the oscillating control hypothesis. Fish Oceanogr 20:139-156

Cressie NAC (1993) Statistics for spatial data (revised edition). Wiley, New York, NY

Danielson S, Eisner L, Weingartner T, Aagaard K (2011) Thermal and haline variability over the central Bering Sea shelf: Seasonal and interannual perspectives. Cont Shelf Res 31:539-554

Doroshenko NV (2000) Soviet whaling for blue, gray, bowhead, and right whales in the North Pacific Ocean, 1961-1979. In: Yablokov AV, Zemsky VA (eds). Center for Russian Environmental Policy, Marine Mammal Council, Moscow
Eisner LB, Napp JM, Mier KL, Pinchuk AE, Andrews III AG (2014) Climate-mediated changes in zooplankton community structure for the eastern Bering Sea. Deep-Sea Res Part II 109:157-171

> Fadely BS, Robson BW, Sterling JT, Greig A, Call KA (2005) Immature Steller sea lion (Eumetopias jubatus) dive activity in relation to habitat features of the eastern Aleutian Islands. Fish Oceanogr 14(Suppl. 1):243-258

Fain SR, LeMay JP (1995) Gender identification of humans and mammalian wildlife species from PCR amplified sex linked genes. Proceedings of the Annual Meeting of the American Academy of Forensic Science, Seattle, Washington, Feb 1995 1:34

Freitas C, Lydersen C, Fedak MA, Kovacs KM (2008) A simple new algorithm to filter marine mammal Argos locations. Mar Mamm Sci 24:315-325

Friday NA, Waite JM, Zerbini AN, Moore SE (2012) Cetacean distribution and abundance in relation to oceanographic domains on the eastern Bering Sea shelf: 1999-2004. Deep Sea Res Part II 65-70:260-272

Friday NA, Zerbini AN, Waite JM, Moore SE, Clapham PJ (2013) Cetacean distribution and abundance in relation to oceanographic domains on the eastern Bering Sea shelf, June and July of 2002, 2008, and 2010. Deep-Sea Res II 94:244-256

Gregr EJ (2011) Insights into North Pacific right whale Eubalaena japonica habitat from historic whaling records. Endang Species Res 15:223-239

Heide-Jørgensen MP, Kleivane L, Oien N, Laidre KL, Jensen MV (2001) A new technique for deploying satellite transmitters on baleen whales: tracking a blue whale (Balaenoptera musculus) in the North Atlantic. Mar Mamm Sci 17:949-954

Hunt GL Jr, Coyle K, Hoffman S, Decker M, Flint E (1996) Foraging ecology of short-tailed shearwaters near the Pribilof Islands, Bering Sea. Mar Ecol Prog Ser 141:1-11

Hunt GL Jr, Stabeno P, Walters G, Sinclair E, Brodeur RD, Napp JM, Bond NA (2002) Climate change and control of the southeastern Bering Sea pelagic ecosystem. DeepSea Res II 49:5821-5853

Hunt GL Jr, Stabeno PJ, Strom S, Napp JM (2008) Patterns of spatial and temporal variation in the marine ecosystem of the southeastern Bering Sea, with special reference to the Pribilof Domain. Deep-Sea Res II 55:1919-1944

Hunt GL Jr, Coyle KO, Eisner LB, Farley EV and others (2011) Climate impacts on eastern Bering Sea foodwebs: a synthesis of new data and an assessment of the Oscillating Control Hypothesis. ICES J Mar Sci 68:1230-1243

IPCC (2007). Climate change 2007: The physical science basis. Contribution of Working Group I to the Fourth Assessment Report of the Intergovernmental Panel on Climate Change. Intergovernmental Panel on Climate Change, Geneva

Ivashchenko Y, Clapham PJ (2012) Soviet catches of bowhead (Balaena mysticetus) and right whales (Eubalaena japonica) in the North Pacific and Okhotsk Sea. Endang Species Res 18:201-217

IWC (2001) Report of the Workshop on the Comprehensive Assessment of Right Whales: A Worldwide Comparison. J Cetacean Res Manage Spec Issue 2:1-60

> Josephson E, Smith TD, Reeves RR (2008) Historical distribution of right whales in the North Pacific. Fish Fish 9: 155-168

Kachel NB, Hunt GL Jr, Salo SA, Schumacher JD, Stabeno PJ, Whitledge TE (2002) Characteristics and variability of 
the inner front of the southeastern Bering Sea. Deep-Sea Res II 49:5889-5909

Kotwicki S, Buckley TW, Honkalehto T, Walters G (2005) Variation in the distribution of walleye pollock (Theragra chalcogramma) with temperature and implications for seasonal migrations. Fish Bull 103:574-587

LeDuc RG, Perryman WL, Gilpatrick JW Jr, Hyde J, Stinchcomb C, Carretta JV, Brownell RL Jr (2001) A note on recent surveys for right whales in the southeastern Bering Sea. J Cetacean Res Manage (Special Issue 2): 287-289

Lee HC, Delworth TL, Rosati A, Zang R and others (2013) Impact of climate warming on upper layer of the Bering Sea. Clim Dyn 40:327-340

Mate BR, Nieukirk S, Kraus SD (1997) Satellite-monitored movements of the Northern right whale. J Wildl Manag 61:1393-1405

Mate BR, Best PB, Lagerquist BA, Winsor MH (2011) Coastal, offshore and migratory movements of South African right whales revealed by satellite telemetry. Mar Mamm Sci 27:455-476

McDonald MA, Moore SE (2002) Calls recorded from North Pacific right whales (Eubalaena japonica) in the eastern Bering Sea. J Cetacean Res Manag 4:261-266

Meier W, Stroeve J, Fetterer F, Knowles K (2005) Reductions in Arctic sea ice cover no longer limited to summer. Eos Trans AGU 86:326

Moore SE, Waite JM, Friday NA, Honkalehto T (2002) Cetacean distribution and relative abundance on the central-eastern and the southeastern Bering Sea shelf with reference to oceanographic domains. Prog Oceanogr 55:249-261

Munger LM, Wiggins SM, Moore SE, Hildebrand JA (2008) North Pacific right whale (Eubalaena japonica) seasonal and diel calling patterns from long-term acoustic recordings in the southeastern Bering Sea, 2000-2006. Mar Mamm Sci 24:795-814

Niebauer HJ, Bond NA, Yakunin LP, Plotnickov VV (1999) An update on the climatology and sea ice of the Bering Sea. In: Loughlin TR, Ohtani K (eds) Dynamics of the Bering Sea. University of Alaska Sea Grant, Fairbanks, Alaska

NMFS (2006) Endangered and threatened species: Revision of Critical Habitat of the northern right whale in the Pacific Ocean. Fed Regist 71:38277-38296

Nuka Research Planning Group (2005) Vessel traffic in the Aleutian Subarea. Report to the Alaska Department of Environmental Conservation, Contract 18-8003-28-09. NUKA, Seldovia, Alaska

Omura H (1958) North Pacific right whales. Sci Rep Whales Res Inst 13:1-52

Omura H, Ohsumi S, Nemoto T, Nasu K, Kasuya T (1969) Black right whales in the North Pacific. Sci Rep Whales Res Inst 33:633-641

Overland JE, Wang MY, Wood KR, Percival DB, Bond NA (2012) Recent Bering Sea warm and cold events in a 95year context. Deep-Sea Res Part II 65-70:6-13

Overpeck JT, Sturm M, Francis JA, Perovich DK and others (2005) Arctic system on trajectory to new, seasonally icefree state. Eos Trans AGU 86:309-313

Rone BK, Berchok CL, Crance JL, Clapham PJ (2012) Using

Editorial responsibility: Per Palsbøll,

Groningen, The Netherlands air-deployed passive sonobuoys to detect and locate critically endangered North Pacific right whales. Mar Mamm Sci 28:E528-E538

Sarmiento JL, Slater R, Barber R, Bopp L and others (2004) Response of ocean ecosystems to climate warming. Global Biogeochem Cycles 18:GB3003, doi:10.1029/ 2003GB002134

Scarff JE (2001) Preliminary estimates of whaling-induced mortality in the 19th century North Pacific right whale (Eubalaena japonicus) fishery, adjusting for struck-butlost whales and non-American whaling. J Cetacean Res Manage Spec Issue 2:261-268

Shelden KEW, Clapham PJ (2006) Habitat requirements and extinction risk of eastern North Pacific Right Whales. AFSC Processed Report 2006-06. US. Department of Commerce, Seattle, WA

> Shelden KEW, Moore SE, Waite JM, Wade PR, Rugh DJ (2005) Historic and current habitat use by North Pacific right whales Eubalaena japonica in the Bering Sea and Gulf of Alaska. Mammal Rev 35:129-155

Sigler MF, Stabeno PJ, Eisner LB, Napp JM, Mueter FJ (2014) Spring and fall phytoplankton blooms in a productive subarctic ecosystem, the eastern Bering Sea, during 1995-2011. Deep-Sea Res II 109:71-83

Smith SL, Vidal J (1986) Variations in the distribution, abundance, and development of copepods in the southeastern Bering Sea in 1980 and 1981. Cont Shelf Res 5:215-239

Stabeno PJ, Bond NA, Kachel NB, Salo SA, Schumacher JD (2001) On the temporal variability of the physical environment over the south-eastern Bering Sea. Fish Oceanogr 10:81-98

> Stabeno PJ, Kachel NB, Moore SE, Napp JM, Sigler M, Yamaguchi A, Zerbini AN (2012) Comparison of warm and cold years on the southeastern Bering Sea shelf and some implications for the ecosystem. Deep-Sea Res II 65-70:31-45

> Stafford KM, Moore SE, Stabeno PJ, Holliday DV, Napp JM, Mellinger DK (2010) Biophysical ocean observation in the southeastern Bering Sea. Geophys Res Lett 37: L02606, doi:10.1029/2009GL040724

> Swartzman G, Stuetzle W, Kulman K, Powojowski M (1994) Relating the distribution of pollock schools in the Bering Sea to environmental factors. ICES J Mar Sci 51:481-492

Tynan CT, DeMaster DP, Peterson WT (2001) Endangered right whales on the southeastern Bering Sea shelf. Science 294:1894

Wade P, Heide-Jørgensen MP, Shelden K, Barlow J, Carretta J, Durban J, LeDuc R, Munger L, Rankin S, Sauter A, Stinchcomb C (2006) Acoustic detection and satellitetracking leads to rare concentration of endangered North Pacific right whales. Biol Lett 2:417-419

Wade PR, Kennedy A, LeDuc R, Barlow J and others (2011) The world's smallest whale population? Biol Lett 7:83-85

Wiese FK, Van Pelt TI, Wiseman WJ (2012) Bering Sea linkages. Introduction. Deep-Sea Res II 65-70:2-5

Zar J (1998) Biostatistical analysis, 4th edn. Prentice Hall, Upper Saddle River, NJ

Zerbini AN, Waite JM, Laake JL, Wade PR (2006) Abundance, trends and distribution of baleen whales off Western Alaska and the central Aleutian Islands. Deep-Sea Res I 53:1772-1790 